\title{
MUSEUMS IN LATE DEMOCRACIES
}

\author{
DIPESH CHAKRABARTY
}

TWO MODELS OF DEMOCRACY

$\mathrm{B}$ efore I get on to the matter of museums and their evolving relationship to democracies - my real subject in this short and sketchy essay - let me begin by explaining briefly what I see as the two models of democracy that coexist and sometimes clash in contemporary democratic polities. In the interest of brevity and exposition, I will keep my models separate and simple. Nineteenthand early twentieth-century ideas of democracy assumed a pedagogical understanding of politics. One was never born political even if it were thought that every human being had the capacity or the potential to take part in political life. But the condition of being human was not equated to the condition of being political. It was assumed that becoming a citizen, possessing and exercising rights, called for appropriate forms of education. Societies were understood to have both high and low forms of culture. Education provided the capacity for discernment - access to high culture - that the citizen needed. This could be self-education. It could be education through the right kind of experience. More commonly, however, it was thought that it fell to the educational institutions of modern societies to provide citizenly competence. Universities, museums, libraries, exhibitions and other comparable bodies assumed this task. ${ }^{1}$ A crucial aspect of this education was the capacity for abstract conceptualisation and reasoning. The book became the key object embodying this assumption. The importance given to the written language as the medium of instruction signified the high place accorded in this mode of thought to the trained, human capacity for abstraction. Abstract reasoning made it possible for the citizen to conceptualise such imaginary lentities as 'class', 'public', or 'national' interest and adjudicate between competing claims. Rationality was not merely a procedural aspect of disputations in life; it was itself thought to be an instrument of unity in public discussions. Rationality could help us appreciate our interests and arrange them mentally in the right order of priority. The public sphere was not only imagined as potentially united and unifiable; such unity was itself a value. For Marxists, 'class' could be the rational key explaining and promoting a unity between diverse underprivileged groups. For nationalists, something like 'national interest' could be a factor that overrode all divisions born of sectional interests. For liberals, rationality could lead to appreciation of that which was in the interest of all. Expanding the area of agreement through education and rational argumentation was seen as way of strengthening the fabric of national life.

This pedagogical understanding of citizenship is not history. It is not something we have left behind. Many of our institutional and personal actions are based on this understanding. Yet twentieth-century practices of mass-democracy - both in the West and in countries such as India - are also predicated on a very different understanding 
of the political. Following Homi Bhabha's usage of the terms 'pedagogic' and 'performative,' we may call the second model of democratic politics a 'performative' one. ${ }^{2}$ The political, in this model, is not fundamentally a matter of pedagogy. The citizen is not someone who comes or is produced at the end of an educational process in which the school, the university, the library, and the museum intervene. In this conception that has increasingly dominated debates in and about public life in democracies since the 1960s, to be human is to be already political. Statements such as 'everything is political,' or 'the personal is political' are reflections of this point of view. An Australian example will illustrate my point about the difference between the two models of democracy. A. P. Elkin, Professor of Anthropology at the University of Sydney from 1934 to 1956, advocated citizenship for Aboriginals but supported only "a gradual granting" of such rights. Only "civilised" Aboriginals, according to him, were fit for citizenship. ${ }^{3}$ Elkin, in my terms, stood for the first model. Yet when Aboriginals finally obtained (partial) citizenship in 1967, the decision obviously did not reflect Elkin's position. ${ }^{4}$ Any Aboriginal, formally educated or not, was now seen as entitled to the rights of the citizen. The same point could be made with respect to the Indian decision, on the attainment of independence, to adopt universal adult franchise as a citizenly right in a society that was predominantly nonliterate. This was part of a global trend the beginnings of which can be traced back at least as far as the 1920s when the fear of Bolshevism, for example, induced Western governments to extend to working classes in many countries the rights of organisation and protest. The acquisition of these rights was no longer made conditional on any preparatory work on behalf of the people. In short, the pedagogical or tutelage model of politics simply could not keep pace with the speed with which the world got politicised last century. The Soviet revolution, anti-colonial mass nationalisms in the nonWest, and emergence of mass politics in the West were important contributors to the process until the 1950s. And then came the 'new' social movements and counter-cultural movements of the 1960s, first-wave feminism with its slogan 'the personal is political', and the politics of multiculturalism and indigenous rights in the Western democracies. The spread of consumerism and the mass media has been an inextricable part of this search for forms of mass democracy. For the rise of the mass-consumer and the question of his or her rights - a growing concern of capitalist democracies - entailed both understandings of the political. The consumer is a subject of pedagogy. She or he is routinely taught many of his or her rights. There are associations and journals that aim to do just that. But the right of a consumer to choose or refuse a product (for whatever reasons) is a basic right, independent of education in these rights.

Understandably, educational institutions such as the university or the museum have not been immune to the growing tension between the pedagogic and performative kinds of democracy. The so-called 'culture wars' of the 1980s that saw the canons of the Western academy being both vigorously challenged and defended, the rise of varieties of cultural relativism, the accent on diversity and the politics of identity, the coming of postmodern and postcolonial criticism, have all left their mark on these institutions. These debates around pedagogic versus performative kinds of democracy are inconclusive but it can be safely said that very few, if any, museums or universities will now want to go back to the purity of nineteenth- or early twentieth-century propositions and ignore the discussions of postcolonial, indigenous and multicultural critics. Nor would they want to deny the reality of consumerist practices within which public institutions are situated. But that said, interesting and rigorous debates still take place in particular institutions about the specific mix of the two models of politics with which particular 
situations should be handled. The ensuing decisions, needless to say, are principled as well as political and pragmatic. They do not offer any universal solutions to our dilemmas but I look on these debates as a reminder of tension between the pedagogic and the performative models of democracy. This tension is what we have to negotiate as we contemplate the futures, in late democracies, of the class of institutions we call 'museums'.

Like the university, the museum also has had to accept that education and entertainment are not opposed to each other. But museums, for reasons I go into below, have been more affected by the process than universities. They have had to embrace the proposition that their clientele have choice and their preferences need to be addressed; that education will largely have to pay for itself and that state-funding will have to be supplemented by endowments and revenue. Along with this have come debates that have challenged the authority of the museum in deciding what could be collected and exhibited. Museums have been drawn into debates about the past, its representation and ownership, debates often driven by the so-called politics of identity. The last point has been a particularly sensitive one for peoples struggling for forms of cultural sovereignty. Indigenous peoples in various parts of world (including Australia) have successfully challenged the idea that everything could be exhibited to anybody or that scientific curiosity represented a greater human interest than a particular group's cultural use and possession of objects. As a result, museums have also emerged as a key site for cultural politics arising over questions of the past in late democracies.

\section{MUSEUMS, DEMOCRACY AND THE POLITICS OF EXPERIENCE}

I want to suggest that if the pedagogic model of democracy privileges the capacity for abstract reasoning and imagination in the citizen, the performative one brings into view the domain of the embodied and the sensual.
And that is what makes the roles of visual and other sensual practices different in the two models. Think of the education that once aimed to give the citizen the capacity to conceive of and visualise abstract things, such as the idea of the nation. There were visual aids, of course: maps, statues and other images of national unity. But the way school and university disciplines such as history, geography, political science and anthropology enabled one to think the nation or community was through developing skills for visualising abstractions. I still vividly remember a question a non-literate peasantgirl who hailed from a village in the district of the 24 Parganas near Calcutta once asked me as she accompanied my cousin, her family and myself making our way to Calcutta from Delhi by car in 1973. A domestic maid in my cousin's home, she had lived in Delhi for quite a few years now and been exposed to television and cinema. And yet, a few miles away from Delhi and her curiosity stoked by unfamiliar surroundings, she asked, "Tell me, Dipeshda [my older brother, Dipesh], is Kashmir a part the 24 Parganas?". We all laughed at her 'ignorance' of Indian geography, but the incident also told me how much one's geographical imagination was a matter of education and training in visualising through instruments such as the map completely imperceptible entities like the nation.

In pedagogic models of democracy, citizenship is based on the capacity for reasoning. This capacity is assumed to stand supreme as the machine through which all information needs to be processed. It is as if the pedagogic model privileges the brain over the senses. The museum of the past would collect and put in juxtaposition objects and artefacts that never belonged together in their natural/cultural distribution in the world. The zoological garden would do the same with animals, and libraries with books. All these arrangements would privilege the conceptual or the analytic over the lived. The zoo would make a catalogue come alive, as it 
were. Museums and archives - both modern institutions for preserving relics of the past were close to each other in principle at their moments of origin. Just as the museum curator ignored the sensory aspects of the exhibits, historians trained in the traditions of their science would seldom include in their narratives the tactile or sensory part of their research. The experience of old brittle documents going to pieces in their hands, the smell of old newspapers, the strain on the eye caused by past styles of handwriting, the allergy attacks they might suffer from the dust in the archives - in short, everything that made the so-called relic of the past a part of the lived present as well — would be put to one side in order for the past to emerge in clear distance from the present. Why would the senses be so relegated to the background in the work of the analytic? Because, it was assumed in this way of thinking, that it was only through analytic reasoning that one reached the deeper, general and invisible 'truths' about society, whatever they were class, economic forces, natural laws. That which was merely perceptual, not subordinated to reason - and, in that sense, part of the lived experience - gave us access to only the local and particular.

The analytic, one might say, always wanted to subordinate 'experience' or the 'lived' to itself. ${ }^{5}$ Yet the realm of experience has asserted itself more and more in academic history or anthropology whenever these disciplines have tried to respond to the pressures of democracy. But not always with happy results. Historians in the 1960s and seventies explored 'oral history' assuming that the experiences reported by people would nicely fill out stories available in the archives, and thus democratise the discipline of history without challenging its basic precepts. Instead they found themselves in the land of memories which always blurred the distinction between the past and the present that was crucial for historical analysis and objectivity. ${ }^{6}$ A disciplinary unease exists between the field of memory and academic history. Anthropologists have similarly wrestled with strategies to release the lived and the experienced from their traditional subjection to analysis but with mixed results. The reasons are not far to seek. The vision of the political that academic disciplines are wedded to belongs to my first model of democracy: citizenship as the capacity for abstract reasoning. Indeed, without such reasoning, the critical-political edge of the social sciences would be blunted. How would you otherwise visualise as concrete and real such invisible entities as capital, social structure, instrumental rationality, and so on? And without these categories, how would one develop modern critiques of social relations?

Museums, being public places where one does not usually require special qualifications to enter, have been more open to the pressure of mass democracies and have had to address more directly issues of experience. They have therefore also had to be more sensitive to the politics that question the presumed primacy of the analytic over the lived. In his well-known essay "On Collecting Art and Culture", the anthropologist James Clifford gives an early instance of this from the life of the Musée de l'Homme in Paris. He cites an essay published in 1986 by Anne VitartFardoulis, a curator at the museum. VitartFarduolis describes how one day a Native American man walked into the museum and suddenly, by talking in a personal and intimate way about "a famous intricately painted animal skin", challenged the primacy of the analytic over the lived:

The grandson of one of the Indians who came to Paris with Buffalo Bill was searching for the [painted skin] tunic his grandfather had been forced to sell to pay his way back to the United States when the circus collapsed. I showed him all the tunics in our collection, and he paused before one of them. Controlling his emotion, he spoke. He told the meaning of this lock of hair, of that design, why this color had been used, the meaning of 
that feather ... This garment, formerly beautiful and interesting but passive and indifferent, little by little became ... [an] active testimony to a living moment through the mediation of someone who did not observe and analyze it but who lived the object and for whom the object lived. It scarcely matters whether the tunic is really his grandfather's.

I do not have to remind the reader that this Native American man could have walked into a museum in the nineteenth century and said the same things but he would not have been heard. Why do we hear him now? Because the politics of identity - the question of who can speak for whom - are, like it or not, part of the cultural politics of a liberal democracy. The more our attention has turned to the formerly 'colonised' within the West, the more anti-colonial themes and questions have come to mark liberal democracies' attempts at multiculturalism. The history of colonialism and of colonial knowledge shows how the universalistic and humanist analytic frames of the social sciences were once used to classify, control and subordinate the colonised both within and outside the West. ${ }^{8}$ It was the same process that also resulted in the pre-colonial knowledge systems of the colonised now living subjugated lives, relegated to the supposedly parochial and untheoretical realms of 'experience'. It is precisely against such politics of knowledge that the cry goes up from time to time from the ranks of the historically-oppressed, "to hell with your archives, we have the experience!".

In opening themselves up to the politics of experience, museums have gradually moved away from the archives, a modern institution with which they once shared paradigms of knowledge. For the politics of experience orients us to the realms of the senses and the embodied. This is never achieved by the capacity for abstract reasoning. It takes us away from the senses, it trains us to be sceptical of the evidence they produce about the

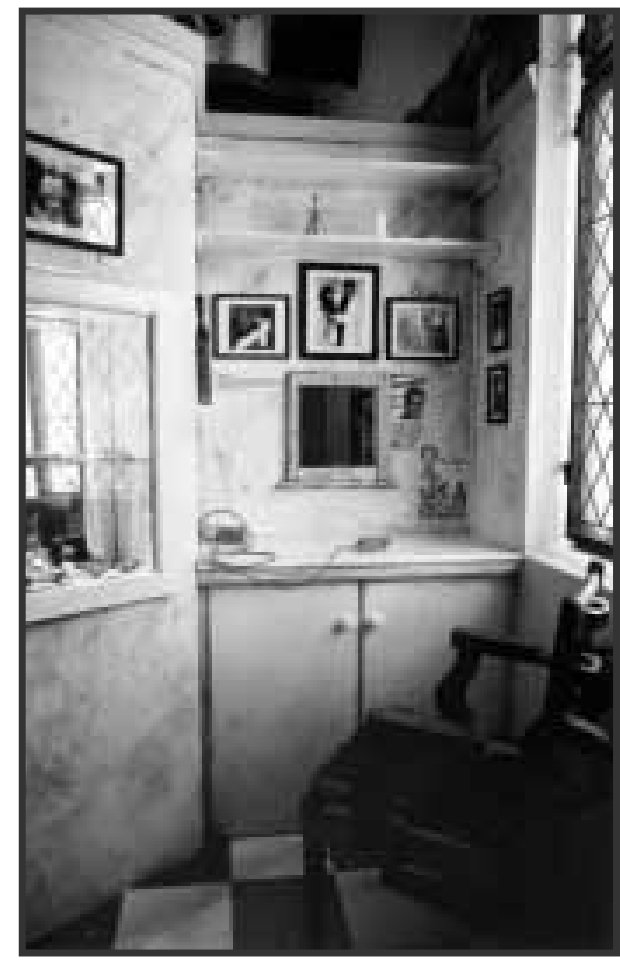

Barber shop installation in the Digging Deeper exhibition at the District Six Museum Cape Town, South Africa.

Photo: Haajirah Esau, (C) District Six Museum.

world. University education, on the other hand, can train us, as I have said, to visualise as concrete that which is invisible to the natural eye. But it speaks to (and of) a disembodied subject of history, a position that we individually are called to inhabit when we know the world from that position. The museum of today, however, increasingly opens itself up to the embodied and the lived. It provides as much 'experience' as abstract knowledge. And this is directly a part of my second model of democracy.

Let me illustrate this briefly with the example of the District Six Museum in Cape Town, South Africa. As many readers will know, District Six was a well-known 'mixed' neighbourhood in Cape Town that was literally bulldozed between 1966 and 1984 to make it into an area for the Whites. Thousands of people lost their dwellings 


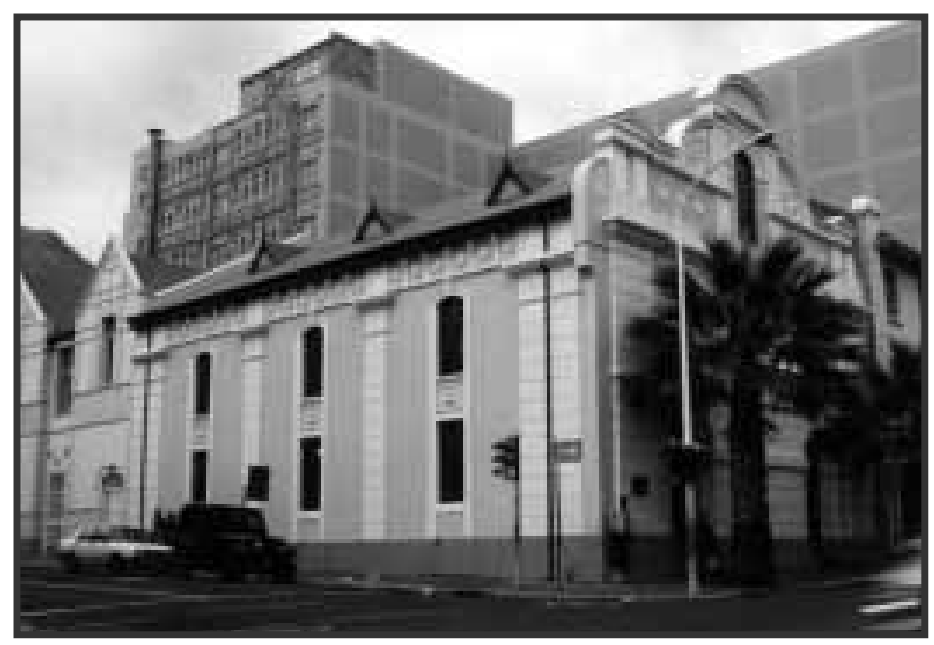

Exterior, District Six Museum. Photo: () District Six Museum. overnight. Families and neighbours were torn apart and dispersed. The museum grew organically out of the protest movement that fearlessly challenged this brutal act of undemocracy. Started in 1994, the museum developed into a site for communal memory, not a nostalgic monument to a dead past but a living memory that is part of the struggle against racism in post-Apartheid South Africa. Older residents and their children visit the museum to imbibe the memories that inform their present struggles. The museum makes special effort to remember the streets of the neighbourhood. Here is a part of a testimony from one of the visitors to the museum, showing how the logic of remembering, as distinct from that of history, leads inexorably to the realms of the sensory and embodied:

The streets of my childhood in Sea Point survive as the bones of an articulated skeleton remain preserved. On visiting there, my memories jostling, it occurred to me that this act of remembering can be likened to watching a video - in reverse motion ... Around the bones grow organs for living and sometimes flesh ... But the process of remembering is filtered and textured, entangling stages of then and now. It culminates in an evocation of old-new things, rather than the 'flesh' of what was once there. A process that is at the same time so intimate and yet beyond our grasp... Along streets we all made our way, linking beacons of home, school and the shop. In a recurring dream verging on nightmare, I pick my way in nauseating dread along the Main Road toward school, bearing a heavy suitcase ... And memories push forward; hot pavements, the scream of seagulls and the droning foghorn, yellowfoaming sea and crackling palm fronds; but the strongest memory-sense of all, the smell of watermelon, permeating from the fresh-cut grass of the beachfront lawns, to the residents of the nearby hotels, flats and scattered houses. ${ }^{10}$

You can see in this quotation how memory, eventually, can never be separated from the domain of the senses, for memory always has elements that are embodied. We cannot even predict these embodied memories in their entirety. This actually produces a paradoxical result for what is often disparagingly called 'identity politics'. It is true that the politics of diverse identities in democracies often lead people to make indefensible claims connecting experience with identity. For instance, it could be claimed - and often is 
- that only the members of a particular group have the right or the capacity to understand/represent the group because they have the necessary and requisite experience. Sometimes, as I have already said, knowing particular histories of oppression helps us to empathise with these claims. But the very nature and politics of experience actually belies such claims. The realm of the lived ultimately belongs to embodied existence. And experience always touches on this level. It follows then that experience does not have to always connote a subject (or an identity) defining the experience as such. Experience is not always subjective in a psychological sense, if by psychology we refer to processes that go on only in the brain. ${ }^{11}$ The body also has experiences and remembers them. The politics of identity thus often reaches out to a level that actually defeats any project that the 'politicians of identity' may have of making identities appear fixed, immutable and essentialised. For who can tell ahead of any event what the mind-body complex may or may not remember? Experience, thus, does not have to speak to a politics of identity.

By opening out to questions of the embodied and the lived, museums address certain formations of the public in modern democracies that academic disciplines do not address. A democracy needs an informed public and public debates. Academic models of knowledge privilege information that, supposedly, the brain processes. These models of knowledge marginalise the senses. Democracies have moved on to a variety of politics in which information is not simply packaged for the brain to process; information is now also what addresses other senses - of seeing, hearing, smelling, and touching. In the democracy of the masses and the media, the realms of the embodied are increasingly politically powerful. It is not that the expertise and rationality produced by the traditional academic disciplines are redundant or irrelevant. But their traditional scepticism towards the embodied and the sensory will not help us in understanding why memory and experience - in other words, embodied knowledge - will play as important roles in the politics of democracies as the disembodied knowledge academic disciplines aspire to. Museums, more than archives and history departments, have travelled the distance needed to keep up with changes that mark late democracies.

\section{Endnotes}

1 See the Introduction to Simon During ed., The Cultural Studies Reader, (London and New York: Routledge, 1999) for a discussion of these issues.

2 Homi Bhabha, "Dissemination: Time, narrative and the margins of the modern nation" in his The Location of Culture, (London and New York: Routledge, 1994), pp. 139-170.

3 Geoffrey Gray, "From Nomadism to Citizenship: A P Elkin and Aboriginal Advancement" in Nicolas Peterson and Will Sanders eds., Citizenship and Indigenous Australians: Changing Conceptions and Possibilities, (Cambridge: Cambridge University Press, 1998), pp. 55-76.

4 For a discussion of the complexities and ambiguities of the 1967 referendum in Australia, see Bain Attwood and Andrew Markus, "Representation Matters: The 1967 Referendum and Citizenship" in Nicolas Peterson and Will Sanders (eds), Citizenship and Indigenous Australians: Changing Conceptions and Possibilities, (Melbourne: Cambridge University Press, 1998), pp. 118-40.

5 See the last chapter to my book Provincializing Europe: Postcolonial Thought and Historical Difference, (Princeton, New Jersey: Princeton University Press, 2000).

6 Joan Scott's much-cited essay, "The Evidence of Experience”, in Critical Inquiry, 17, Summer 1991, pp. 772-797, reproduces, this time with a poststructuralist suspicion of the subject, the social analyst's scepticism about the usefulness of "experience" as a guide to social realities.

7 Vitart-Fardoulis cited in James Clifford, "On Collecting Art and Culture" in his The Predicament of Culture: Twentieth-Century Ethnography, Literature, and Art, (Cambridge, Mass.: Harvard University Press, 1988), p. 246. Emphasis added.

8 Bernard Cohn, Colonialism and its Forms of Knowledge, (Princeton, New Jersey: Princeton University Press, 1998) is a classic statement of some of the issues involved here. 
9 I discuss this more in my essay "Globalization, Democratization, and the Evacuation of History?" in Jackie Assayag and Veronique Benei (eds), East in West, (Delhi: Permanent Black, forthcoming).

10 Lalou Meltzer, "Past Streets" in Ciraj Rasool and Sandra Prosalendis (eds), Recalling Community in Cape Town, (Cape Town: District Six Museum, 2001), pp. 21-22.

11 Joan Scott's essay "The Evidence of Experience" seems to make this assumption. 